\title{
Nutritional Status of Mentally Disabled Children in Egypt
}

\author{
*Asmaa M AbdAllah, **Shawkia S. A. El-Sherbeny and ***Sahar Khairy \\ * Clinical Nutrition Department, Nutrition Institute. \\ **Nutritional Biochemistry Department, Nutrition Institute \\ *** Nutritional Requirement and Growth Department, Nutrition Institute
}

\begin{abstract}
Introduction: Mental disability can interfere with education and scholastic achievement. It can lead to school dropout and minimize opportunities to participate in the labor force. Moreover, disabilities affect the overall health and psychological state of the individuals.

Objective: The aim of the present study was to assess the nutritional status of mentally disabled children in Egypt on the basis of anthropometric indicators and laboratory data.

Subjects and Methods: Across sectional study was conducted on 639 mentally disable children aged $6-<14$ years (422males and 217 females), from urban areas. They were classified into two age groups $(6-<11 \& 11-<14$ years). The following variables were determined using $\mathrm{Z}$ score indicator of weight for age, height for age and weight for height. Also, body mass index, mid arm circumference and triceps skin fold thickness percentiles were determined. Laboratory investigation including blood hemoglobin concentration and plasma levels of vitamin A and $\alpha$ tocopherol as well as plasma zinc, copper and magnesium concentration were estimated.

Results: Prevalence of underweight was $14.1 \%$ by Wt/age $\mathrm{Z}$ score. Stunting was estimated among $33.5 \%$ with significantly higher prevalence in older children. Muscle \&fat depletion was detected in $30.2 \%$, with significantly higher prevalence among males than females. Depleted fat store was detected in $14.7 \%$ of children. Wasting was documented in $14.1 \%$ of children by BMI percentile, and was significantly higher among males than females. No significant difference was detected between male and female handicapped children regarding mean blood hemoglobin values as well as mean plasma levels of the measured vitamins and minerals, except for mean plasma zinc level. The overall prevalence of iron deficiency anemia was higher in males (41.5\%) than females (37.1\%). Deficiency of $\alpha$ tocopherol was more prevalent than that of vitamin A. The overall prevalence of deficiency of zinc, magnesium and copper was $1.8 \%, 40 \%$, and $25.3 \%$ respectively. The decline in anthropometric measurements was associated with the decline in socioeconomic status.

Conclusion: Malnutrition as revealed by anthropometric variables and micronutrient deficiency occurs with a high prevalence among mentally disabled children and almost increased with age and low socioeconomic level.

Key words: Mental handicap- Children- Anthropometric measurements- Social statusBlood hemoglobin- Plasma- Vitamin A- $\alpha$-tocopherol- Zinc-Copper-Magnesium.
\end{abstract}

\section{Introduction}

Adequate nutrition is a fundamental prerequisite for good physical health, motor and cognitive development and social development, (Waterlow, 1994). Malnourished children can become adults with lower physical and intellectual abilities, lower levels of productivity and higher levels of chronic illness and disability, (UNICEF, 1998). Poverty and malnutrition have serious adverse consequences for the health, wellbeing and development of children (Crabb, 2000). Economic conditions may influence the parent's responses to their children's condition. (Mallory et al., 1993).

Disabled people are often assumed to have poorer nutrition than their nondisabled counterparts, they are also vulnerable to poor nutritional care (Bax, 1993). This is the situation in developed 
countries. In contrast, far less information is available on the nutritional status of disabled children in developing countries, where the situation is further complicated by widespread malnutrition among the general population (Tompsett et al., 1999). Disabled children are known to be at high risk for developing malnutrition, which may partly explain the growth retardation often encountered in such children and associated complications experienced in later life as adults (Hals et al., 1996).

The most common problems associated with malnutrition in disabled children, are inadequate nutrient intake either due to feeding problems or poor feeding knowledge among care providers. (Suzuki et al., 1991). Constipation, gastro-esophageal reflux, poor health status and respiratory infections are additional problems (Shaw, 1996; Fung et al., 2002).

In developed countries, the prevalence of severe mental retardation in childhood was ranged from 3-5 per 1000. Higher prevalence was found in less developed countries (5-25 per 1000) due to increased frequency of nutritional, traumatic and infectious causes of brain damage (Wallace, 2002). In Egypt, there are about 23000 mental retarded adolescents (aged 10-20 years) according to the last census in 1996 (Census, 1996).

Studies focusing on nutritional status of mentally disabled children are underestimated in Egypt. The objective of this study is to assess the nutritional status of mentally disabled children on the basis of anthropometric and some biochemical indicators in order to prevent nutritional deficiency. Through the development of nutritional strategy directed towards prevention and management of malnutrition and general wellbeing of mentally handicapped children, this goal can be achieved.

\section{Subjects and methods}

This study was apart of a across sectional survey conducted by National Nutrition Institute titled "Towards strategy for Nutrition improvement of Handicapped children in Arab Republic of Egypt". It included 639 mentally disabled children (without any associated disability) aged from 6-<14 years, (422 males 217 females). The Studied Children were classified into two age groups $(6-<11$ years) and $(11-<14$ years) and were recruited from urban areas of six Governorates (Cairo as capital city, Alexandria the costal area, Gharbia \& Dakahlia representing Lower Egypt and Assiut \& Quena for upper Egypt) ,the majority $443(69.3 \%)$ of children were from schools and 196 (30.7\%) from establishments.

\section{1-Anthropometric measurements:}

The following anthropometric measurements were carried out using standardized methods:

\section{Weight:}

Individuals were weighed with light clothes and bare footed using platform bath scale, the weight was measured to the nearest $0.1 \mathrm{~kg}$. (WHO, 1983).

\section{Height:}

A vertical scale fixed to the wall was employed. After removing the shoes, the individual was instructed to stand on a flat platform feet parallel and with heels, buttocks, shoulders and back of head touching the upright, the head was in Frankfort position. Height was recorded to the nearest $0.5 \mathrm{~cm}$ (Jelliffe et al., 1989).

\section{Mid-Arm Circumference (MAC):}

The arm circumference was measured to the nearest $0.1 \mathrm{~cm}$ with a flexible nonstretched tape and the left arm was used for measurement. (Jelliffe et al. , 1989).

\section{Triceps Skinfold (TSF) thickness:}

The site was carefully selected at a measured point half-way down the arm, between the tip of the olecranon process of the scapula and the acromial process of the ulna, at the back of the upper left arm by using skinfold caliper (Jelliffe et al., 1989).

All the instruments were verified before to measure each subject (Jelliffe, 1966; Gibson, 1990).

The nutritional status was determined by using standard deviation scores from (version, 1990) as height for age (Ht/A), weight for age (Wt/A) and weight for height $(\mathrm{Wt} / \mathrm{Ht})$ according to the international reference population (WHO, 
1983). Body mass index (BMI) percentile was calculated for assessment of nutritional Status of children (9- <14 years) guided from (Dennis, 2001).

Mid arm circumference (MAC) and Triceps skinfold thickness (TSF) percentiles were determined according to American Academy of Pediatrics, (1998).

\section{2- Socioeconomic status:}

The social standing of mentally disabled individuals was classified as low, intermediate and high levels based on education and occupation scoring system of father and mother according to Park and Park (1979).

\section{3-Biochemical measurements:}

Blood samples were collected from target individuals, hemoglobin concentration (593 samples) was determined as described by Drabkin and Austim (1935). Plasma was separated by centrifugation and kept frozen under $-20^{\circ} \mathrm{C}$ for further investigation. Vitamin $\mathrm{A}$ and $\alpha$-tocopherol (152 samples for each) was carried out as described by Bieri et al (1979). Atomic absorption spectrometer (Unicam 929) was used for the determination of plasma levels of zinc (284 samples), copper (277 samples) and magnesium (190 samples) according to the method described by AOAC (1990)

Cut off points for hemoglobin was $<12 \mathrm{~g} / \mathrm{dl}$ (WHO,1995). 20-80 ug/dl for vitamin A (WHO/UNICEF, 1994), 5-17 $\mathrm{mg} / \mathrm{L}$ for $\alpha$ - tocopherol; 78-136 ug/dl for zinc; $80-150 \mathrm{ug} / \mathrm{dl}$ for copper and 1.6-2.2 $\mathrm{ug} / \mathrm{dl}$ for magnesium (Fischbach, 2000).

\section{4-Statistical analysis:}

The data was subjected to statistical analysis using computer program (SPSS, 1996). Chi-Squared test $\left(X^{2}\right)$ was used to determine significant differences between the categorical variables $(\mathrm{P}<0.05)$ (Guilford \& Fruchter, 1984).

\section{Results}

Table (1) shows the criteria of the studied individuals by age, sex and socioeconomic status.

The total sample included 639 mentally disabled children, 422 (66.0\%) males and 217(34.0\%) females. They were Classified into two age groups; $(6-<11$ years) represented $240(37.6 \%)$ and (11$<14$ years) represented $399(62.4 \%)$.

The majority of mentally disabled individuals (77.3 percent) were from low social level, 16.7 percent was in intermediate class and 4 percent was at high social status. Eleven males and two females had no information about their parents or their social standing. This may be due to being orphans, Criminals or found less.

Table (2) shows the anthropometric data of the studied children by mean and standard deviation according to age group and sex.

The mean values of weight, mid arm circumference and triceps skinfold was higher among females than males, while the mean value of height was higher among males and the difference between age and between sexes was insignificant.

Table (3) shows the prevalence of malnutrition among the studied targets according to anthropometric categories by age group and sex.

Prevalence of underweight $(\mathrm{Wt} / \mathrm{A}<-$ 2SD) was 14.1 percent among the studied individuals, the higher prevalence $(15.8 \%)$ was found among age group $(11-<14$ years), and among males (15.9\%) more than females $(10.6 \%)$, while the difference between age and /or sex was not significant.

Prevalence of overweight (Wt/A >+ 2SD) was 6.7 percent among the studied individuals and no significant difference between either age or sex was found.

Concerning height for age (Ht/A); the over all prevalence of stunting was 33.5 percent. The prevalence of stunting was significantly higher $(\mathrm{P}<0.05)$ among older age group compared with the younger one, as $35.3 \%$ and $30.4 \%$ was stunted at age (11$<14$ years) \& $(6-<11$ years $)$ respectively. Females showed higher prevalence $(37.8 \%)$ than males $(31.3 \%)$ with no significant difference.

Tall stature was representing 1.6 percent of the studied mentally disabled individuals . The number of tall individuals was few for statistical evaluation.

Regarding mid arm circumference for age (MAC/A); 
Overall, the prevalence of muscle and fat depletion (MAC Age $\leq 5^{\text {th }}$ percentile) was $30.2 \%$ of the studied individuals. Muscle and fat depletion goes with age, about one third $(32.3 \%)$ of the older individuals $(11-<14$ years $)$ had muscle and fat depletion while $26.7 \%$ in the younger age (6-< 11 years) had muscle and fat depletion. The depletion was significantly $(\mathrm{P}<0.004)$ higher among males $(34.8 \%)$ than females $(21.2 \%)$.

Few individuals $(2.5 \%)$ were at higher percentile ranking (MAC/A $\geq 95 \%$ ) with statistically significant difference $(\mathrm{P}<$ $0.004)$ between sex, $(2.8 \%$ of females VS $2.4 \%$ of males).

\section{Regarding triceps skin fold thickness for age (TSF/A):}

About 14.7 percent of the studied individuals had lower fat fold (TSF/A $\leq 5^{\text {th }}$ percentile). Higher prevalence of lower fat fold $(17.9 \%)$ was found among younger age (6-<11 years), compared with $12.8 \%$ among age groups $(11-<14$ years). And among females $(15.7 \%)$ more than males $(14.2 \%)$. with no significant difference either between age and or sex. About 4.5 percent of the studied individuals had greater fat fold (TSF/A $\geq 95^{\text {th }}$ percentile) and no significant difference was found between both age groups and or sex.

Table (4) shows the prevalence of malnutrition among the studied targets according to body mass index (BMI) category by age group and sex.

Above one eighth $(14.1 \%)$ of the studied individuals were wasted $\left(\mathrm{BMI} \leq 5^{\text {th }}\right.$ percentile). Wasting was 12.4 percent among age group $(9-<11$ years) and 14.9 percent among older age $(11-<14$ years $)$ with no significant difference.

Prevalence of wasting was significantly higher $(\mathrm{p}<0.001)$ among males $(17.2 \%)$ than females $(7.9 \%)$.

The overall prevalence of obesity was found to be 12.0 percent, Prevalence of obesity increased with age as $11.3 \%$ \& $12.3 \%$ at age $(9-<11$ years $\& 11-<14$ years $)$ respectively and there was highly statistically significant difference $(\mathrm{P}<0.001)$ between sex goes towards females $(15.8 \%)$ than males $(10.2 \%)$.

For children below nine years; weight for height standard deviation score indicator was used, the wasted children $(\mathrm{Wt} / \mathrm{Ht}<-$ 2SD) were 6.2 percent (representing 4 individuals). While over weight children $(\mathrm{Wt} / \mathrm{Ht}>+2 \mathrm{SD})$ were 18.5 percent $(12$ cases) out of 65 child total, with no significant difference between sex. They were not tabulated because their number was not effective statistically.

\section{Socioeconomic status:}

Table (5) shows the distribution of the studied individuals by socioeconomic status and under nutrition data. It was observed that $74.2 \%$ of the under weight children coming from low socioeconomic status (table, 5). Higher percent $(76.8 \%)$ of the stunted children was of low socioeconomic level vs. $19 \%$ of the intermediate class. Also, $77.6 \%$ of children with muscle and fat depletion were found in low socioeconomic level vs. $18.8 \%$ of the intermediate group. About $84.9 \%$ of the Depleted fat stores children were found in the low socioeconomic class vs. $11.8 \%$ in the intermediate group.

\section{3-Biochemical results:}

Table (6) showed the mean hemoglobin values of mentally handicapped children. However, no significant differences were found between male and female of the studied age groups.

Prevalence of iron deficiency anemia (table, 7), were higher among males $(41.5 \%)$ than females $(37.1 \%)$ of total mentally disabled children. However, for the age group 6-11 years, anemia was more prevalent in females (27.6) than males (23.9) handicapped children. While, for the age group 11-14 years, the prevalence was higher in males (51.6) than females (42.6).

Table (8) showed mean plasma levels of the measured vitamins and minerals. All mean values were within the normal range, except for mean plasma zinc concentration which was higher than the cut off points. However, no significant differences were defected between males and females regarding all parameters, except for mean plasma zinc levels where the difference between males and females were significant.

Prevalence of plasma vitamin A deficiency was $5.9 \%, 5.8 \%$ and $6.1 \%$ for males, females and total mentally handicapped children respectively, table (8). 
However, $\alpha$ - tocopherol deficiency was more prevalent with percentages of $17.4 \%$ (for males), $11.9 \%$ (for females) and $15.0 \%$ (for the whole sample).

With regard to mineral deficiency, (table, 9) the highest prevalence of deficiency was observed for magnesium with percentages of $37.9 \%, 46 \%$ and $40 \%$ for males, females and total mentally disabled children respectively. While, zinc deficiency were lower with percentages of 2.0 (for males), $1.1 \%$ (for females) and $1.8 \%$ (for total sample). Moreover, deficiency of copper have percentages of $23.7 \%$ ( for males), $28.7 \%$ (for females and $25.3 \%$ for total mentally handicapped children.

Table (1): Criteria of the studied individuals regarding age, sex and socioeconomic status.

\begin{tabular}{|c|c|c|c|c|c|c|c|}
\hline \multirow[t]{2}{*}{ Criteria } & & \multicolumn{2}{|c|}{ Males } & \multicolumn{2}{|c|}{ Female } & \multicolumn{2}{|c|}{ Total } \\
\hline & & No & $\%$ & No & $\%$ & No & $\%$ \\
\hline \multirow{5}{*}{ Age groups } & 6- <11yrs & 157 & 37.2 & 83 & 38.3 & 240 & 37.6 \\
\hline & Mean \pm SD & $9.1 \pm 0.9$ & & $8.9 \pm 1.1$ & & $9.0 \pm 0.9$ & \\
\hline & $11-<14 y r s$ & 265 & 62.8 & 134 & 61.7 & 399 & 62.4 \\
\hline & Mean \pm SD & $12.1 \pm 0.8$ & & 12. \pm 00.7 & & $12.1 \pm 0.8$ & \\
\hline & Total & 422 & 100 & 217 & 100 & 639 & 100 \\
\hline \multirow{6}{*}{$\begin{array}{c}\text { Socioeconomic } \\
\text { status }\end{array}$} & Low & 329 & 77.6 & 165 & 76.0 & 494 & 77.3 \\
\hline & Med & 66 & 15.6 & 41 & 18.9 & 107 & 16.7 \\
\hline & High & 16 & 3.8 & 9 & 4.2 & 25 & 4.0 \\
\hline & Total & 411 & 97.4 & $\begin{array}{c}215 \\
2\end{array}$ & $\begin{array}{c}99.1 \\
0.9\end{array}$ & $\begin{array}{c}626 \\
13\end{array}$ & 98.0 \\
\hline & Missing & $\begin{array}{c}11 \\
422\end{array}$ & $\begin{array}{l}2.6 \\
100\end{array}$ & 217 & 100 & 639 & 2.0 \\
\hline & G total & & & & & & 100 \\
\hline
\end{tabular}

$\%=$ Column percent

Table (2): Anthropometric data by mean and standard deviation according to age group and sex.

\begin{tabular}{|c|c|c|c|c|c|c|c|c|c|c|}
\hline \multicolumn{2}{|l|}{ Age groups } & \multicolumn{3}{|c|}{$6-<11$ years $=240$} & \multicolumn{3}{|c|}{$11-<14$ years=399 } & \multicolumn{3}{|c|}{ Total $=639$} \\
\hline anthrop. Data & Sex & n. & Mean & SD & n. & Mean & SD & n. & Mean & SD \\
\hline \multirow[t]{3}{*}{ Wt (kg) } & Male & (157) & 27.9 & 6.5 & (265) & 37.3 & 9.0 & $(422)$ & 33.8 & 8.0 \\
\hline & female & (83) & 28.6 & 7.0 & (134) & 41.1 & 10.0 & (217) & 36.3 & 8.0 \\
\hline & Total & $(240)$ & 28.2 & 7.0 & (399) & 38.5 & 9.5 & (639) & 34.6 & 8.5 \\
\hline \multirow[t]{3}{*}{$Z$ score } & Male & (157) & -0.3 & 0.07 & $(265)$ & -0.57 & 0.14 & (422) & -0.5 & 0.1 \\
\hline & female & (83) & 0.2 & 0.05 & (134) & -0.19 & 0.04 & (217) & 0.2 & 0.05 \\
\hline & Total & (240) & -0.3 & 0.07 & (399) & -0.45 & 0.1 & (639) & -0.4 & 0.11 \\
\hline \multirow[t]{3}{*}{$\overline{\mathrm{Ht}(\mathrm{cm})}$} & Male & (157) & 125.9 & 10.6 & $(265)$ & 139.1 & 14.2 & $(422)$ & 134.2 & 14.5 \\
\hline & female & (83) & 124.4 & 11.4 & (134) & 137.8 & 19.7 & (217) & 132.7 & 18.1 \\
\hline & Total & (240) & 125.5 & 10.9 & (399) & 138.7 & 16.3 & (639) & 133.6 & 15.8 \\
\hline \multirow[t]{3}{*}{$Z$ score } & Male & (157) & -1.1 & 0.3 & $(265)$ & -1.36 & 0.3 & $(422)$ & -1.3 & 0.3 \\
\hline & female & $(83)$ & -1.2 & 0.2 & (134) & -1.67 & 0.4 & (217) & -1.5 & 0.4 \\
\hline & Total & (240) & -1.2 & 0.3 & (399) & -1.46 & 0.4 & (639) & -1.3 & 0.3 \\
\hline \multirow[t]{3}{*}{$\overline{\mathrm{MAC}(\mathrm{cm})}$} & Male & $(157)$ & 18.5 & 4.0 & $(265)$ & 20.6 & 4.5 & $(422)$ & 19.9 & 4.5 \\
\hline & female & $(83)$ & 19.0 & 4.0 & (134) & 21.7 & 3.9 & (217) & 20.6 & 4.5 \\
\hline & Total & (240) & 18.7 & 4.6 & (399) & 21.1 & 5.4 & (639) & 20.2 & 5.0 \\
\hline \multirow[t]{3}{*}{ TSF (mm) } & Male & $(157)$ & 8.8 & 2.0 & $(265)$ & 10.7 & 2.6 & $(422)$ & 10.0 & 2.3 \\
\hline & female & $(83)$ & 10.3 & 2.5 & (134) & 13.3 & 3.3 & (217) & 12.2 & 3.0 \\
\hline & Total & (240) & 9.3 & 2.3 & (399) & 11.6 & 2.5 & (639) & 10.7 & 2.5 \\
\hline
\end{tabular}


Table (3):Prevalence of malnutrition among mentally disabled children according to anthropometric categories by age groups, sex and socioeconomic status.

\begin{tabular}{|c|c|c|c|c|c|c|c|c|c|c|c|c|c|c|c|c|}
\hline \multirow{3}{*}{$\begin{array}{l}\text { Anthropometric } \\
\text { Category }\end{array}$} & \multicolumn{4}{|c|}{$\begin{array}{c}\text { Wt/age } \\
\text { Z score }\end{array}$} & \multicolumn{4}{|c|}{$\begin{array}{c}\text { Ht/ Age } \\
\text { Z score }\end{array}$} & \multicolumn{4}{|c|}{$\begin{array}{l}\text { MAC/ Age } \\
\text { Percentile }\end{array}$} & \multicolumn{4}{|c|}{$\begin{array}{c}\text { TSF/ Age } \\
\text { Percentile }\end{array}$} \\
\hline & \multicolumn{2}{|c|}{$\begin{array}{l}\text { Under weight } \\
<-2 \mathrm{SD}\end{array}$} & \multicolumn{2}{|c|}{$\begin{array}{l}\text { Over weight } \\
>+2 \mathrm{SD}\end{array}$} & \multicolumn{2}{|c|}{$\begin{array}{l}\text { Stunted } \\
<-2 \mathrm{SD}\end{array}$} & \multicolumn{2}{|c|}{$\begin{array}{c}\text { Tall } \\
>+2 \mathrm{SD}\end{array}$} & \multicolumn{2}{|c|}{\begin{tabular}{c|}
$\leq \mathbf{5}^{\text {th }}$ \\
Percentile
\end{tabular}} & \multicolumn{2}{|c|}{$\begin{array}{c}\geq \mathbf{9 5}^{\text {th }} \\
\text { Percentile }\end{array}$} & \multicolumn{2}{|c|}{$\begin{array}{c}\leq 5^{\text {th }} \\
\text { Percentile }\end{array}$} & \multicolumn{2}{|c|}{$\begin{array}{c}\geq 95^{\text {th }} \\
\text { Percentile }\end{array}$} \\
\hline & No. & $\%$ & No. & $\%$ & No. & $\%$ & No. & $\%$ & No. & $\%$ & No. & $\%$ & No. & $\%$ & No. & $\%$ \\
\hline Age groups & & & & & & & & & & & & & & & & \\
\hline $6-<11 \mathrm{yrs}(240)$ & 27 & 11.3 & 21 & 8.8 & 73 & 30.4 & 7 & 2.9 & 64 & 26.7 & 9 & 3.8 & 43 & 17.9 & 13 & 5.4 \\
\hline \multirow[t]{2}{*}{$11-<14 y r s(399)$} & 63 & 15.8 & 22 & 5.5 & 141 & 35.3 & 3 & 0.8 & 129 & 32.3 & 7 & 1.8 & 51 & 12.8 & 16 & 4.0 \\
\hline & \multicolumn{4}{|c|}{ N.S } & \multicolumn{3}{|c|}{$\begin{array}{cc}X^{2} & \text { df } \\
5.75 & 2 \\
\end{array}$} & $\begin{array}{c}\mathbf{P} \\
0.05\end{array}$ & \multicolumn{4}{|c|}{ NS } & \multicolumn{4}{|c|}{ NS } \\
\hline$\underline{\text { Sex }}$ & & & & & & & & & & & & & & & & \\
\hline Males (422) & 67 & 15.9 & 27 & 6.4 & 132 & 31.3 & 7 & 1.7 & 147 & 34.8 & 10 & 2.4 & 60 & 14.2 & 21 & 5.0 \\
\hline \multirow[t]{2}{*}{ Females (217) } & 23 & 10.6 & 16 & 7.4 & 82 & 37.8 & 3 & 1.4 & 46 & 21.2 & 6 & 2.8 & 34 & 15.7 & 8 & 3.7 \\
\hline & \multicolumn{4}{|c|}{ N.S } & \multicolumn{4}{|c|}{ N.S } & $\begin{array}{c}X^{2} \\
13.3 \\
\end{array}$ & & & $\begin{array}{l}\mathbf{P} \\
0.004 \\
\end{array}$ & \multicolumn{4}{|c|}{ N.S } \\
\hline Total (639) & 90 & 14.1 & 43 & 6.7 & 214 & 33.5 & 10 & 1.6 & 193 & 30.2 & 16 & 2.5 & 94 & 14.7 & 29 & 4.5 \\
\hline
\end{tabular}

$\%=$ Row Percent

Table (4) Prevalence of malnutrition among the studied targets according to body mass index (BMI) category by age group and sex.

\begin{tabular}{|c|c|c|c|c|}
\hline & \multicolumn{2}{|c|}{$\leq 5^{\text {th percentile }}$} & \multicolumn{2}{|c|}{$\geq 95^{\text {th percentile }}$} \\
\hline \multirow{5}{*}{$\begin{array}{c}\text { Age groups } \\
9-<11(177) \\
11-<14(397) \\
\text { Total(574) } \\
\text { Sig. }\end{array}$} & NO. & $\%$ & NO. & $\%$ \\
\hline & 22 & 12.4 & 20 & 11.3 \\
\hline & 59 & 14.9 & 49 & 12.3 \\
\hline & 8.1 & 14.1 & 69 & 12.0 \\
\hline & \multicolumn{4}{|c|}{ NS } \\
\hline \multirow{4}{*}{$\begin{array}{c}\underline{\text { Sex }} \\
\text { Males (348) } \\
\text { Females (190) } \\
\text { Total (574) }\end{array}$} & & & & \\
\hline & 66 & 17.2 & 39 & 10.2 \\
\hline & 15 & 7.9 & 30 & 15.8 \\
\hline & 81 & 14.1 & 69 & 12.0 \\
\hline Sig & \multicolumn{2}{|c|}{$\begin{array}{r}\chi^{2} \\
16.4\end{array}$} & \multicolumn{2}{|c|}{$\begin{array}{c}\mathbf{p} \\
0.001\end{array}$} \\
\hline
\end{tabular}

$\%=$ Row percent

Table (5): Distribution of the studied individuals by socioeconomic status and under nutrition data:

\begin{tabular}{|c|c|c|c|c|cc|c|c|}
\hline $\begin{array}{c}\text { Anthropometric } \\
\text { parameters }\end{array}$ & \multicolumn{2}{|c|}{$\begin{array}{c}\text { Wt/age } \\
\text { Z score }<-2 S D\end{array}$} & \multicolumn{2}{|c|}{$\begin{array}{c}\text { Ht/age } \\
\text { Z score }<-2 S D\end{array}$} & \multicolumn{2}{|c|}{$\begin{array}{c}\text { MAC } \leq \mathbf{5}^{\text {th }} \\
\text { Percentile }\end{array}$} & \multicolumn{2}{|c|}{$\begin{array}{c}\text { TSF } \leq \mathbf{5}^{\text {th }} \\
\text { Percentile }\end{array}$} \\
\hline Socioeconomic & No. & $\mathbf{\%}$ & No. & $\mathbf{\%}$ & No. & \% & No. & $\%$ \\
\hline Low (494) & 66 & 74.2 & 162 & 76.8 & 149 & 77.6 & 79 & 84.9 \\
\hline Mid. (107) & 19 & 21.3 & 40 & 19.0 & 36 & 18.8 & 11 & 11.8 \\
\hline High (25) & 4 & 4.5 & 9 & 4.2 & 7 & 3.6 & 3 & 3.3 \\
\hline Sig. & \multicolumn{2}{|c|}{ N.S } & \multicolumn{2}{|c|}{ N.S } & \multicolumn{2}{|c|}{ N.S } & \multicolumn{2}{|c|}{ N.S } \\
\hline T (626) & $\mathbf{8 9}$ & $\mathbf{1 0 0}$ & $\mathbf{2 1 1}$ & $\mathbf{1 0 0}$ & $\mathbf{9 2}$ & $\mathbf{1 0 0}$ & $\mathbf{9 3}$ & $\mathbf{1 0 0}$ \\
\hline
\end{tabular}


Table (6): Mean hemoglobin values (g/dl) of mentally handicapped children (Mean \pm SD)

\begin{tabular}{|c|c|c|c|}
\hline Age group & Males & Females & Total \\
\hline $6<11$ years & $12.18 \pm 1.72$ & $12.03 \pm 1.2$ & $12.13 \pm 1.73$ \\
\hline $11<14$ years & $11.84 \pm 1.56$ & $12.12 \pm 1.86$ & $11.94 \pm 1.68$ \\
\hline Total & $11.96 \pm 1.63$ & $12.09 \pm 1.82$ & $12.01 \pm 1.70$ \\
\hline
\end{tabular}

Table (7): Distribution of mentally handicapped children in relation to prevalence of anemia

\begin{tabular}{|c|c|c|c|c|c|c|c|}
\hline \multirow[b]{2}{*}{ Age group } & \multirow{2}{*}{$\begin{array}{l}\text { Cut off } \\
\text { points }\end{array}$} & \multicolumn{2}{|c|}{ Male } & \multicolumn{2}{|c|}{ Female } & \multicolumn{2}{|c|}{ Total } \\
\hline & & No. & $\%$ & No. & $\%$ & No. & $\%$ \\
\hline $6<11$ years & $12-14$ & $34(142)$ & 23.9 & $21(76)$ & 27.6 & $55(218)$ & 25.2 \\
\hline $11<14$ years & $\mathrm{g} / \mathrm{dl}$ & $127(246)$ & 51.6 & $55(129)$ & 42.6 & $182(375)$ & 48.5 \\
\hline Total & & $161(368)$ & 41.5 & $76(205)$ & 37.1 & $237(593)$ & 40.0 \\
\hline
\end{tabular}

-Numbers between practices represent the total number of target individuals

Table (8): Mean plasma levels of vitamins and minerals of mentally handicapped children (Mean \pm SD

\begin{tabular}{|c|c|c|c|}
\hline Parameters & Males & Females & Total \\
\hline $\begin{array}{c}\text { Vitamin A } \\
(\mathrm{ug} / \mathrm{dl})\end{array}$ & $42.83 \pm 7.01$ & $40.47 \pm 8.96$ & $41.87 \pm 8.13$ \\
\hline $\begin{array}{c}\alpha-\text { tocopherol } \\
(\mathrm{ug} / \mathrm{dl})\end{array}$ & $10.86 \pm 1.90$ & $10.52 \pm 2.00$ & $10.71 \pm 1.93$ \\
\hline $\begin{array}{c}\text { Zinc } \\
(\mathrm{ug} / \mathrm{dl})\end{array}$ & $166.11 \pm 31.21^{*}$ & $180.43 \pm 36.23$ & $170.65 \pm 33.54$ \\
\hline $\begin{array}{c}\text { Copper } \\
\text { ug/dl) }\end{array}$ & $106.11 \pm 21.21$ & $105.60 \pm 22.21$ & $105.95 \pm 21.47$ \\
\hline $\begin{array}{c}\text { Magnesium } \\
(\mathrm{ug} / \mathrm{dl})\end{array}$ & $1.88 \pm 0.32$ & $1.72 \pm 0.32$ & $1.84 \pm 0.32$ \\
\hline
\end{tabular}

$*_{-} \mathrm{P}<0.05$

Table ( 9 ): Distribution of mentally handicapped children in relation to percent deficiency of the measured plasma vitamins and minerals

-Numbers between practices represent the total number of target individuals

\begin{tabular}{|c|c|c|c|c|c|c|}
\hline \multirow{2}{*}{ Parameters } & \multicolumn{2}{|c|}{ Males } & \multicolumn{2}{c|}{ Females } & \multicolumn{2}{c|}{ Total } \\
\cline { 2 - 7 } & No. & $\%$ & No. & $\%$ & No. & $\%$ \\
\hline $\begin{array}{c}\text { Vitamin A } \\
(20-80 \mathrm{ug} / \mathrm{dl})\end{array}$ & $5(86)$ & 5.8 & $4(66)$ & 6.1 & $9(152)$ & 5.9 \\
\hline $\begin{array}{c}\alpha-\text { Tocopherol } \\
(5.5-17 \mathrm{mg} / \mathrm{L})\end{array}$ & $15(86)$ & 17.4 & $8(67)$ & 11.9 & $23(153)$ & 15.0 \\
\hline $\begin{array}{c}\text { Zinc } \\
(78-136 \mathrm{ug} / \mathrm{dl})\end{array}$ & $4(196)$ & 2.0 & $1(88)$ & 1.1 & $5(284)$ & 1.8 \\
\hline $\begin{array}{c}\text { Copper } \\
(80-150 \mathrm{ug} / \mathrm{dl})\end{array}$ & $45(190)$ & 23.7 & $25(87)$ & 28.7 & $70(277)$ & 25.3 \\
\hline $\begin{array}{c}\text { Magnesium } \\
(1.6-2.2 \mathrm{ug} / \mathrm{dl})\end{array}$ & $53(140)$ & 37.9 & $23(50)$ & 46 & $76(190)$ & 40 \\
\hline
\end{tabular}




\section{Asmaa M AbdAllah et al}

\section{Discussion}

In Egypt studies focusing on nutritional status of mentally disabled children are scarce. This study was done to assess the nutritional status of those children on the basis of anthropometric parameters and laboratory data.

The results of our study found that, the overall prevalence of moderate to severe malnutrition by weight for age category (the most reliable indicator of nutritional status) was 14.1 percent of the studied children table(3). This may be due to resent episodes of illness or acute food shortage that insufficient to meet the child's growth needs.

Our results goes with the results of Tompsett et al. (1999), who found that children with mixed disability had significantly disadvantaged weight for age compared to both non-disabled sibling and neighbors.

Also, the older children were disadvantaged $(15.8 \%)$ than younger one $(11.3 \%)$ by weight for age category and malnutrition goes towards males $(15.9 \%)$ more than females $(10.6 \%)$. The results of Nutrition Institute survey (1995) was recorded lower percentage $(11.1 \% \quad \& 7.4 \%)$ of normal males and females respectively. This may be due to that the majority of the studied children were from establishments under poor nutritional care and poor financial resources.

Prevalence of over weight was 6.7 percent among the studied subjects, higher percent was found in younger children and among females more than males. On their study, Rubin et al. (1998) reported significantly higher prevalence of overweight in mentally disabled individuals than general population.

Stunting was estimated in one third of the studied population $(33.5 \%)$ table(3). The prevalence of long term under nutrition was significantly increased with advancing age and females tend to suffer from stunting more than males. Although, slow height velocity is observed in some mentally disabled as Down syndrome, inappropriate dietary intake relative to nutritional needs and increased nutrient losses may account for the poor nutritional status of those individuals. Also, children may be present with excessive drooling and persistent tongue thrust resulting in food loss through spillage (Peckenpaugh, 2003).Moreover, mentally disabled persons residing in institutions or establishment were dependent on their caregivers for their nutrient intake and their quality of life. The role of institutions in the care of mentally disabled has come into question recently and need to be reevaluated.

Among general urban population, stunting was representing $11.8 \%$ and $17.9 \%$ for ages $(6-<10$ years and 10- $<14$ years) respectively, as recorded in Nutrition Institute survey (2000).

Body fat and arm muscle area can be estimated from mid arm circumference and triceps skin fold thickness (Marchand et al., 2006).

Depletion of muscle and fat stores was recorded in 30.2 percent of the children, the prevalence was higher among older children. While males showed highly significant depletion than females table (3).Thin musculature indicating poor protein and caloric reserve will be due to low socioeconomic status and institution living that decrease and limit dietary intake. Also, thin musculature will be due to either poor development or wasting or both.

Depletion of fat stores was reported among 14.7 percent of the studied subjects, with higher prevalence of fat depletion among younger children than older one, as well as among females more than males table (3).

The presence of chronic energy deficiency was proposed since 14.1 percent of the study population had body mass index below or equal the fifth percentile $\left(\mathrm{BMI} \leq 5^{\text {th }}\right)$ table (4). Wasting was higher among older age and the disadvantage was significantly towards males more than females. This may be due to recurrent episodes of illness and or failure to receive adequate nutrition to meet the child's growth needs. Our results was higher than that of Marais's study, (2000) who found prevalence of $10 \%$ of mentally disabled children with moderate malnutrition by weight for height percentile. 
On the other hand, obesity in persons with developmental disability can contribute to the development of chronic diseases such as diabetes, hypertension and heart disease (Rubin et al, 1989).

Our results estimated 12 percent obese children, obesity increased with age and were significantly higher among females more than males. This goes with the results of Bertoli et al. (2006) on older age, who found $14 \%$ obese individuals. Also, Cronk et al. (1988) found that body fatness for children with Down syndrome (one of mental disability) was above normal. Also, mentally disabled individuals may be overweight as a result of a sedentary life style and over eating (Suzuki et al., 1991).

Our results goes with Shaboyeky (2004) ,based on BMI prevalence of obesity was higher among mentally disabled females.

The overall decline in anthropometric scores was associated with the decline in socioeconomic status table (5).

The high prevalence of iron deficiency anemia among mentally disabled children (table, 6) may be related to low dietary iron intake, especially from animal sources. Animal sources of iron are more readily absorbed than plant ones (Hurrell, 1997). Iron deficiency anemia is associated with impaired cognition and it has an adverse effect on school performance of children. Beside being associated with impaired mental development which is long lasting and perhaps irreversible, despite the correction of anemia, iron deficiency during the first years of life was proven to be associated with increased absorption of lead, so these young children are doubly at risk for neurodevelopment impairment, both from the iron deficiency itself as well as from CNS damage caused by the associated increased lead absorption (Edin et al., 2005).

Warner (2001) concluded that serum vitamin A levels were found to be lower in individuals with Down syndrome (mental disorder), possibly due to malabsorption. These finding may explain the vitamin A deficiency found in the present study. However, other workers failed to confirm these findings (Baer et al., 1990). It has been speculated that the alteration of the conjuctival epithelium in patients with
Down syndrome may be due to altered metabolism of vitamin A (Filippello et al., 1997).

Cengiz and Seven (2000) found that the average serum levels of zinc was higher in Down syndrome patients. This result may explain the higher mean plasma zinc values obtained in the present study.

Molteno et al. (2000) found normal copper levels in Down syndrome patients. This finding may support that of the present study. However, Down syndrome patients often been found to have elevated levels of copper, in erythrocytes, neutrophils, platelets and serum (Werbach, 1999). The high prevalence of plasma copper deficiency in the present study may be attributed to low dietary intake of copper.

Anneren (1985) found that magnesium levels were lower in erythrocytes and thrombocytes of Down syndrome patients. Moreover, Monteiro et al. (1997) found lower red blood cell levels of magnesium in the down syndrome patients as compared to the non-down's group. These results may confirm those of the present study.

\section{Conclusion}

Malnutrition as revealed by anthropometric variables and micronutrient deficiency occurs with a high prevalence among mentally disabled children and almost increased with age and low socioeconomic level. Attention towards the nutritional status of mentally disabled individuals is needed and adequate nutritional support is requested to restore linear growth, normalize weight, and improve health and quality of life.

The golden rule of avoiding and preventing the potential and actual detrimental effects of malnutrition by providing an optimal diet must be one of the major considerations in their care .We remain dependent however, on further research in this field and a national policy that will help improve their overall care and management.

\section{References}

1. American Academy of Pediatrics (1998): B. Appendix (pediatric Guidelines) 
Appendix I. Procedures for measuring Growth parameter. Committee on Nutrition. Pediatrics(ed4):PP 168-174.

2. American Dietetic Association (1992): Position of the American Dietetic Association- Nutrition in Comprehensive programme planning for persons with developmental disabilities. J. Am. Diet. Assoc. 92: 613-615.

3. Anneren G, Johansson $\mathbf{E}$ and Lindu $\mathbf{U}$ (1985): Trace element profiles in individual blood cells from patients with Down's syndrome. Acta Paediatr Scand., 74(2):259263

4. AOAC (1990): Official Methods of Analysis, $5^{\text {th }}$ edn. Wilson Baulevard Arligton (edn.) The Association of Official Analytical Chemists. Inc. Arlington, Vergnia, USA.

5. Baer, M.T, Waldron J., Gumm H, Van Dyke DC and Chang H (1990): Nutrition assessment of the child with Down syndrome. In Clinical Perspectives in the Management of Down Syndrome. SpringerVerlag, NY,:107-125

6. Bax M (1993): Nutrition and disability. Dev. Med. Child. Neurol., 35: 1035-1036 (editorial).

7. Bertoli S, Battezzati A., Merati G, MargonatoV and Maggioni $M$ (2006): Nutritional status and Dietary patterns in disabled people. Nutr. Metab. Cardiovasc. Dis., 16 (2): 100-12.

8. Bieri JG, Tolliver BS and George $\mathbf{L}$ (1979): Simultaneous determination of $\alpha$ tocopherol and retinol in plasma or red blood cell by high pressure liquid chromatography. Am. J. Clin. Nutr., 32:2143-2149.

9. Cengiz M. and Seven M. (2000): Vitamin and mineral status in Down syndrome. Tracw Elem. Elec. 17(3): 156-160

10. Census (1996): "Proportional Distribution of Egyptian Disableds by kind of Disability and sex in all governorates". Source (APMAS. Egypt).

11. Crabb C (2003): UNICEF report has grave implication for childhood disability in the people's republic of China. Child care health Dev., 19(2): 71-81.

12. Cronk C, Croker AC and Pueschel SM et al. (1988): Growth charts for children with Down syndrome: 1month to 18 years of age. Pediat., 81:102-110.

13. Dennis MS (2001): Childhood and adolescent obesity. Pediatric clinic of North America ,48 (4) p. 445.

14. DHSE (2002): Demographic Health Survey of Egypt.
15. Drabkin DL and Austim J H (1935): J. Biol. Chem. 112:51.

16. Drake L, Maier C, Jukes M, and Patrikios A (1999): School age children: Their Health and Nutrition. A periodic Review of Developments in International Nutrition. SCN News.

17. Edin AN(2005): Iron deficiency and impaired cognition in toddlers an underestimated and under treated problem. Pediatric Drugs, 7 (6): 447-52.

18. Filippello M., Cascone G., Zagami A and Scimone G. (1997): Impression cytology in Down's syndrome. Br. J. Opthalmol.,81 (8) :683-685.

19. Fischbach F (2000): A manual of laboratory diagnostic tests. Sixth edition. Lippincott Philadelphia. New York. p. 1189.

20. Fung EB, Samson-Fang $L$ and Stallings VA (2002): Feeding dysfunction is associated with poor growth and health status in children with cerebral palsy. J. Am. Diet. Assoc., 102: 361-373.

21. Guilford JP and Fruchter B (1984): Estadistica Aplicada a/a psychologiala Education (Fundamental statistics in Psychology and education). Mexico: Mc Grow Hill.

22. Hurrell RF (1997): Bioavailability of iron. European J. of Clin. Nutr., 51 (1): 54-58.

23. Jelliffe DB (1966): The Assessment of the Nutritional status of the community, Geneva: WHO.

24. Jelliffe DP, Jelliffe EFP, Zerfas A, and Neumann GG. (1989): Community Nutritional Assessment. Oxford New York, Oxford University press.

25. Krezel, W, Kastner, Pand Chambon, $\mathbf{P}$ (1999): Neuroscience 89: 1291-1300.

26. Linder, M.G. (1996): Copper; in Ziegler, E.E. Jiler, L.J. Jr (eds.): Present Knowledge in Nutrition, ed 7. Washington, ILSI Press, pp: 307-319

27. Mallory BL, Nichols RW, Charlton JI and Marfo K (1993): Traditional and changing views of Disability in developing societies: causes, consequences, cautions. Durham: world Rehabilitation Fund- the International Exchange of Experts and Information in Rehabilitation, the University of New Hampshire, NC, USA.

28. Mangelsdorf D J, Umesono $\mathbf{K}$ and Evans R M (1994): in the Retinoids: Biology, Chemistry, and Medicine, eds. Sporn, M. B., Roberts, A. B. and Goodman, D. S. (Raven, New York), $2^{\text {nd }}$ Ed., pp. 319-349.

29. Marais M. L (2000): The mentally disabled-a responsibility and a challenge. 
SAJ Clin. Nutr. 13(4): 123-130

30. Marchand V, Motil KJ and the NSAPGHA N Committee on Nutrition (2006): Nutrition Support for neurologically impaired Children: A clinical report of the North American Society for pediatric gastroenterology, hepatology, and Nutrition. Journal of Pediatric gastroenterology and Nutrition, 43: 123-135.

31. Molteno C., Smit I., Mills J. and Huskisson J. (2000): Nutritional status of patients in a long-stay hospital for people with mental handicap. S. Afr. Med. J.,90(11): 1135-1140.

32. Monteiro C.P., Varela A., Pinto M., Neves J., Felisberto G.M., Vaz C., Bicho M.P.and Laires M.J. (1997): Effects of an aerobic training program on magnesium, trace elements and antioxidant systems in Down syndrome population. Magnes Res., 10(1):65-71.

33. Nutrition Institute Survey (1995): National Survey for assessment of vitamin A status in Egypt Nutrition Institute in collaboration with UNICEF .

34. Nutrition Institute Survey (2000): Food consumption pattern and nutrient intake among different population groups Nutrition Institute, Carioo, Egypt. Supported by WHO/EMRO.

35. Olanow,C.W.andArendash,G.W.(1994): Metals and free radicals in neurodegeneration. Curr. Opin. Neurol., 7(6):548-558.

36. Park JE and Park K (1979): Text Book of Preventive and social Medicine, Seventh Edition. Page 81. Hessers Barinar Sides, ph. Not publisher, 1268 Napier Town.

37. Peckenpaugh N. P (2003): Nutrition Essential and diet therapy $9 \frac{\text { th }}{}$ ed. Sauder S., London, Toronto, Chapter 13: 355-393.

38. Rubin SS, Rimmer JH, Chicoine B, Braddock D, MC Guire DE. (1998): over weight prevalence in persons with Down syndrome. Ment. Retard., 36: 175-187.

39. Shabayek (2004): Assessment of the nutrional status of children with special needs in Alexandria: 1. Nutrient intake and food consumption. J. Egypy. Public Health Assoc. 79 (3-4_: 225-41.

40. Show BNJ (1996): the respiratory consequences of neurological deficit. In Feeding the Disabled child, clinics in Development Medicine, PP. 40-46
[Sullivan PB and Rosen boom L., editors]. London and Cambridge, UK: MacKeith press Cambridge University Press.

41. SPSS (1996): Staistical package for social science computer soft ware version 8 (USA) on an IBM, PC Computer Bailey (1994).

42. Suzuki M, Saitoh S, Tasaki Y, Shimomura Y, Makishima $R$ and Hosoya N (1991): Nutritional status and daily physical activity of handicapped students in Tokyo metropolitan schools for deaf, blind, mentally retarded and physically handicapped individuals. Am J. clin. Nut., 54: 1101-1111.

43. Tompsett J, Yousafzai AK and Filteau SM (1999): The nutritional Status of disabled children in Nigeria- a crosssectional survey. Eur. J. clin. Nutr. 53: 915919.

44. UNICEF (1998): The state of the world's children, New York: Oxford University Press.

45. Version 1. 0.112 December (1990): Division of Nutrition, Centers for Disease Control in Collaboration with Nutrition Unit; World Health organization.

46. Warner F.J. (2001): Nutrition and Down syndrome. Presentation at the third Annual Convention of the California State Naturopathic Medical Association, Buena Park, February 11.

47. Werbach M. (1999): Down syndrome. In Textbook of Nutritional Medicine. Third Line Press, Tarzana (CA): 340-348.17-

48. WHO (1983): Measuring changes in Nutritional status. Guidelines for Assessing the Nutritional Impact of supplementary feeding programmes for vulnerable groups WHO, Geneva, 1983.

49. WHO/UNICEF (1994): Joint statement to XVI AVACG meeting participants. In report of XVI International vitamin A consultative group Meeting 24-28 04.Chiang Bai Thailand.

50. WHO (1995): World Health Organization: "Guidelines for the control of the eastern Mediterranean, Middle East and North Africa" Joint WHO/UNISEF consultation on strategies for control of iron deficiency anemia, hold at the Institute for Nutrition and Food technology, in Tehran, Islamic Republic of Iran from 22 to 26 October, 1995. 


\title{
الحالة التغذوية للأطفال ذوى الإعاقة الذهنية فى مصر
}

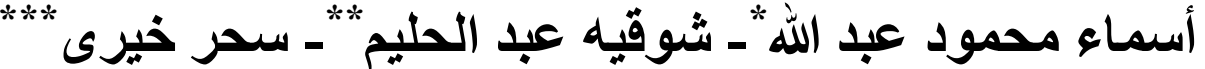

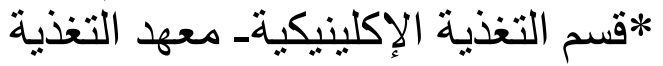

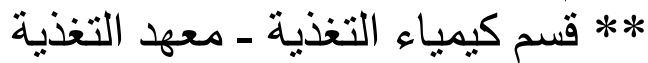 \\ ***** قمم الاحتياجات الغذائية و النمو - معهد التغذية الغنية
}

مقدمة: للإعاقة الذهنية تأثثير سلبي على الناحيـة التعليميـة و التحصيل الدر استي عمومـاً

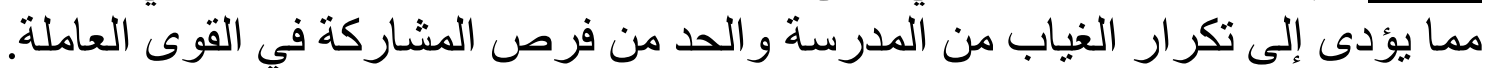

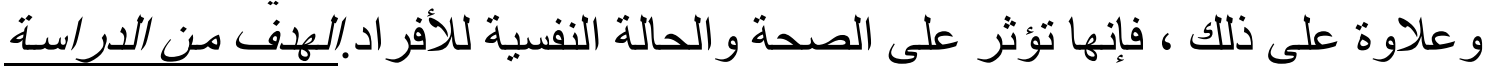

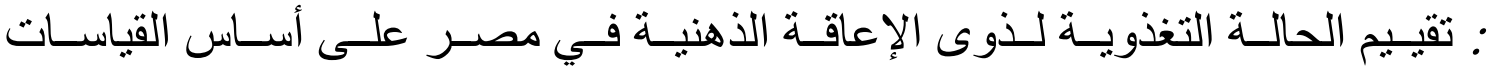

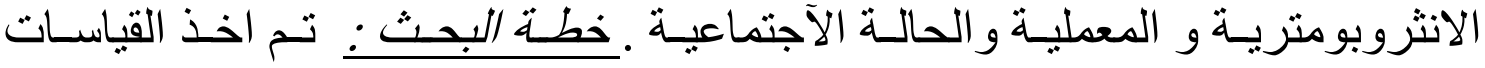

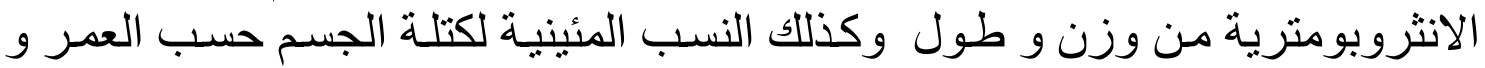

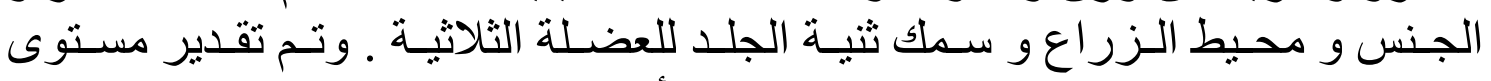

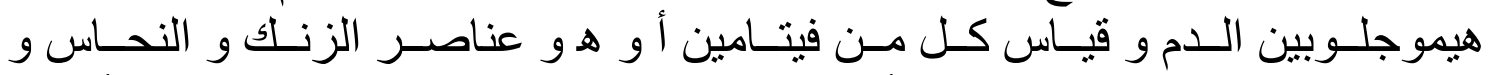

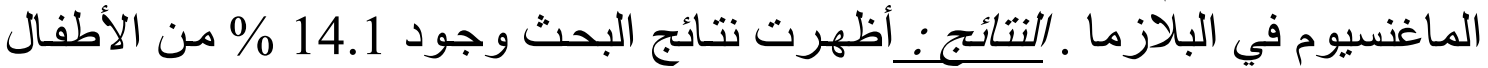

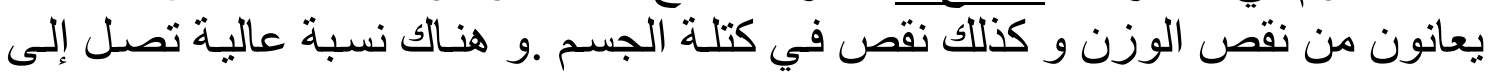

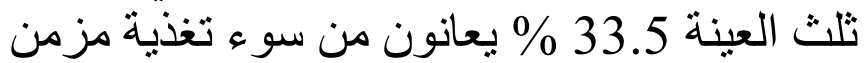

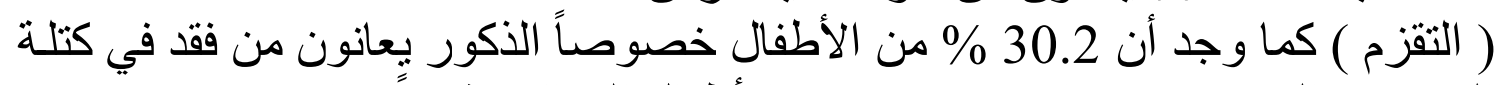

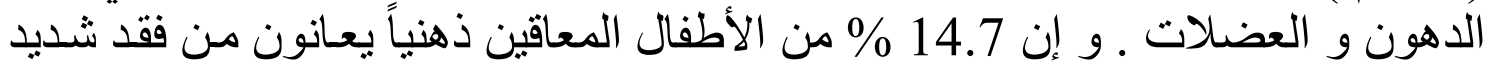

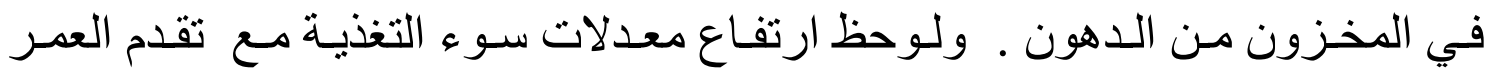

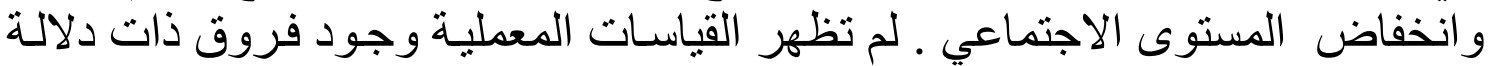

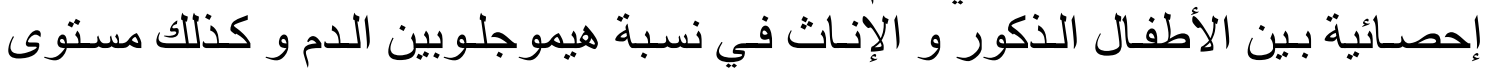

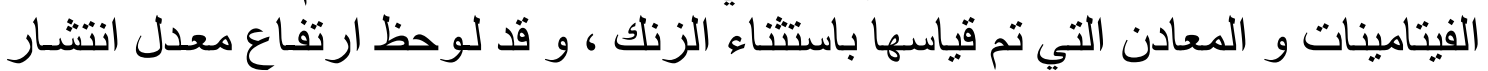

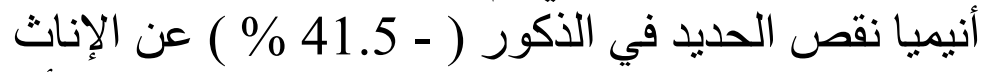

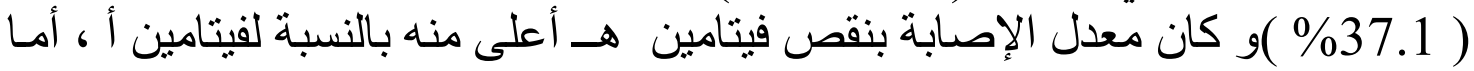

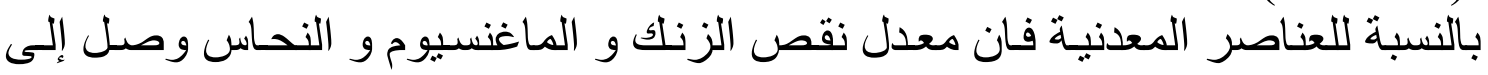
1.8 \% و 40 \% و 25.3 \% \% على الترتيب .

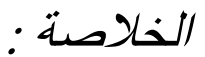

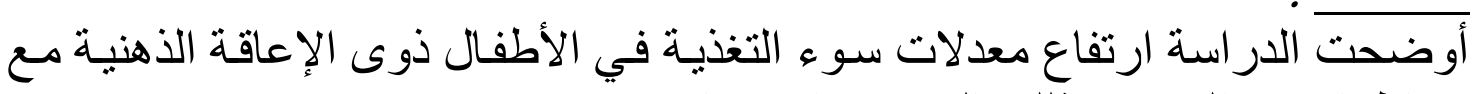

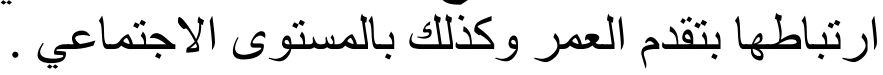

